\title{
HUMAN IMPACTS ON WATER QUALITY IN COLDWATER SPRING, MINNEAPOLIS, MINNESOTA
}

\author{
Sophie M. Kasahara \\ Civil, Environmental and Geoengineering Department, University of Minnesota, 122 Civil \\ Engineering Building, 500 Pillsbury Dr. SE., Minneapolis, MN 55455, kasah007@umn.edu
}

Scott C. Alexander

Earth Sciences Department, University of Minnesota, 310 Pillsbury Dr. SE, Minneapolis, MN 55455, alexa017@umn.edu

\section{E. Calvin Alexander Jr.}

Earth Sciences Department, University of Minnesota, 310 Pillsbury Dr. SE, Minneapolis, MN 55455,

alexa001@umn.edu

\begin{abstract}
Coldwater Spring in Minneapolis, Minnesota was the water supply for Fort Snelling from the 1840s to 1920. The spring site has been declared a sacred site by some federally recognized Native American tribes. The site is managed by the National Park Service. This project has monitored the water chemistry of Coldwater Spring to document human impacts on the spring's water quality. Temperature, dissolved oxygen, conductivity, $\mathrm{pH}$ and anions were monitored weekly and cations and alkalinity monitored monthly at Coldwater Spring and the adjacent Wetland A from 15 February 2013 through 18 January 2015. Coldwater Spring's water flows through fractures in Platteville Limestone of Ordovician age. The basic chemistry of Coldwater Spring should be the calcium magnesium bicarbonate water typical of carbonate springs. However, on an equivalent basis, Coldwater Spring's water currently contains almost as much sodium as calcium + magnesium and more chloride than bicarbonate.
\end{abstract}

The chloride concentrations are about 100 times the levels from 1880. Maguire (1880) reported the chloride levels of Coldwater Spring were about $4.5 \mathrm{ppm}$. During the current study the chloride content in the spring increased from about $320 \mathrm{ppm}$ from March 2013 to about 410 ppm in December 2014. In April, May, and June of 2013 and 2014, the chloride rose about $100 \mathrm{ppm}$ in three month-long pulses. The chloride concentration of the water in Wetland A ranges from about $400 \mathrm{ppm}$ to over $600 \mathrm{ppm}$ with a pattern that is a mirror image of the Coldwater Spring pattern. This major anthropogenic chloride component has a chloride to bromide ratio of $2,500 \pm 300$, well within the range of chloride to bromide ratios of road salt, 1,000 to 10,000 . Road salt is applied to two major multi-lane highways close to the spring and is used extensively in this heavily urbanized area throughout the winter.

The temperature of the spring is variable and higher than its pre-settlement temperature. Nicollet (1841) recorded the temperature of Coldwater Spring multiple times in summer of 1836 as $46^{\circ} \mathrm{F}\left(7.8^{\circ} \mathrm{C}\right)$ and multiple times in winter of 1837 as $45.5^{\circ} \mathrm{F}\left(7.5^{\circ} \mathrm{C}\right)$. More recently the temperature of Coldwater Spring fluctuates smoothly between 10.7 and $13.1^{\circ} \mathrm{C}$. The higher temperature of the springs' discharge also indicates an anthropogenic source of heat within the spring-shed or spring recharge area. The spring water is coldest in May and June and warmest in October and November. The temperature of the water in Wetland A fluctuates from 6.4 to $13.8^{\circ} \mathrm{C}-$ in a pattern that is opposite of that in Coldwater Spring.

Coldwater Spring also contained a significant, increasing nitrate-nitrogen component which ranged from 2.5 to $5.2 \mathrm{ppm}$ - with dips at the same times as the chloride pulses. Wetland A's nitrate-nitrogen level varied between 0.2 to almost $6 \mathrm{ppm}$ with large pulses at the same time as Coldwater Spring's dips. A 2014 study performed by the US Geological Survey came to the conclusion that increasing chloride levels in lakes and streams are likely driven by increasing road salt application, rising baseline concentrations, as well as an increase in snowfall in the Midwestern area of the US during the time of the study (Corsi 2014). The significant chloride, temperature and nitrate levels are likely to be driven by anthropogenic sources. 


\section{Introduction}

This project monitored the water quality in Coldwater Spring, Minneapolis, Minnesota, to evaluate the impact of anthropogenic pollutants on the spring and an adjacent wetland ("Wetland A"). This report expands and adds a second year of data to Kasahara's (2014) report on the first year's results of this project.

In the Twin Cities Metropolitan area (TCMA), roughly 350,000 tons of de-icing road salt is applied to the TCMA roads every year (Sander et al., 2007). The majority of this salt dissolves in snowmelt that either flows overland to surface water bodies or infiltrates to recharge the water table. According to a recent study about $70 \%$ of the road salt applied in the Twin Cities area stays in the regions' watershed (Rastogi, 2010). The road salt used is about $60 \%$ chloride and $40 \%$ a positive ion, usually sodium, and is generically referred to as $\mathrm{NaCl}$ (Keseley, 2007). This road salt runoff can lead to high levels of salinity in freshwater areas due to the dissolution of $\mathrm{NaCl}$ in the water. This is harmful to freshwater aquatic life, regional mammals and birds, and plants native to Minnesota.

\section{Salinity Effects on Wildlife}

Ten percent of freshwater species can die off after just 30 days at salinity concentrations of $220-240 \mathrm{ppm}$, trout behavior is affected at levels as low as $250 \mathrm{ppm}$, and the overall diversity of aquatic species decreases as the salinity concentration rises (Keseley, 2007). According to the Minnesota Pollution Control Agency's (MPCA) 2010 draft report, 11 metro-area streams have levels of chloride concentration above $230 \mathrm{ppm}$ (Homstad, 2010). Road salt particles may attract moose and deer to roadsides, where cars or trucks may strike them, and birds, such as sparrows, can die after eating only two salt particles. Plants as far as 200 feet away from the roadside can still be affected by the rise in salinity, and just a 30 ppm concentration can lead to damage to coniferous species such as the pine tree (Keseley, 2007). Because groundwater is the source for drinking wells, high levels of salinity can also affect humans on restricted-sodium diets (Rastogi, 2010).

\section{The Sample Sites}

Coldwater Spring is located at $44^{\circ} 53^{\prime} 57.61^{\prime \prime} \mathrm{N} ; 93^{\circ}$ 11 ' 47.81" W. Coldwater Spring is an important Native American cultural site (NPS, 2012) and is an integral part of the history of Fort Snelling and Minneapolis. The spring site is now a part of the National Park Service's
Mississippi River National River and Recreation Area (NPS, 2012) and is open to the public.

The Minnesota Department of Health test results of the spring water in 2005 revealed the presence of bacteriological contamination of total coliform indicating organisms, but did not detect E. coli. The NPS has posted signage at the spring indicating the water is not suitable for drinking.

Figure 1 is an aerial view of Coldwater Spring area. Coldwater Spring is in a highly urbanized area in the southeast corner of Minneapolis, Minnesota. A major trunk highway/light rail interchange is immediately west of the spring. The large white squares visible northwest of the spring are buildings of a VA Medical center. Runway 22-4 of the MSP International Airport extends into the southwest corner of Figure 1. St. Paul, Minnesota is across the Mississippi River to the east- northeast.

The groundwater in the Coldwater Spring region typically flows from west to east toward the Mississippi River, and recharges from precipitation and lakes such as Lake Nokomis and Mother Lake. The bedrock geology of this area is of \pm 26 feet of Platteville Limestone and a variety of soils, which overlays \pm 3 feet of Glenwood Shale (Howe 2014). Both these layers overlie a highly permeable layer of St. Peter Sandstone. The Platteville Limestone is often described as being two different layers, Upper and Lower Platteville, because of the differing amounts of shale content. In the Lower Platteville Limestone, the shale comprises greater than $30 \%$ of the Platteville's composition, while the Upper Platteville has a much lower shale contents. The Lower Platteville Limestone thus has a lower conductivity and acts as a

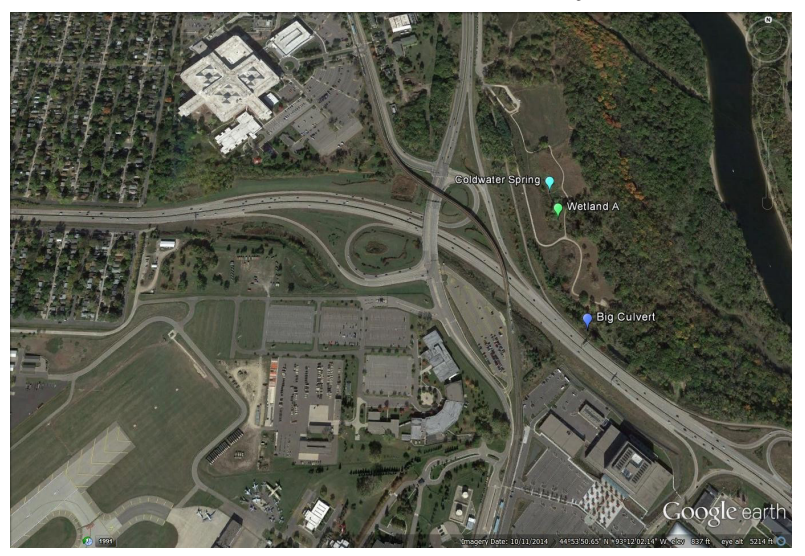

Figure 1. An aerial view of the Coldwater Spring site. 
confining layer for the Upper Platteville Limestone. Water in the Upper Platteville Limestone has easy horizontal flow paths (Howe 2014). Coldwater Spring's water flows through fractures in the Upper layers of Platteville Limestone of Ordovician age. Studies of this formation have shown that it is ineffective at filtering out many of the contaminants from the recharge areas, in this case runoff from residential housing and major highways (NPS, 2012).

The Wetland A sample site is a reconstructed wetland. The Wetland A previously had a building from the former Bureau of Mines, Twin Cities Research Center (TCRC) situated adjacent to it. The TCRC was closed in 1996 and the building removed in 2012. The adjacent historic springhouse and reservoir were left intact as the restoration of the Coldwater Spring site was completed by the National Park (NPS, 2012). Wetland A is located at $44^{\circ} 53^{\prime} 55.14^{\prime \prime} \mathrm{N}$; $93^{\circ} 11^{\prime} 46.91^{\prime \prime} \mathrm{W}$.

The "Big Culvert" is a 6-foot diameter storm water outlet that drains the area southwest of the Coldwater Spring site. It flows perennially and was sampled twice late in this project. The Big Culvert is located at $44^{\circ} 53^{\prime}$ $47.91 " \mathrm{~N}$; $93^{\circ} 11^{\prime} 44.81$ ” W.

\section{Methodology}

Weekly visits were conducted to Coldwater Spring and Wetland A to record the temperature, to measure the conductivity, dissolved oxygen and $\mathrm{pH}$ levels of the spring using a Thermo Orion multi-meter, and to collect weekly anion samples. The Coldwater Spring samples were collected at the outfall pipe on the southwest corner of the springhouse structure. The anion samples were analyzed using ion chromatography [EPA 300.0]. Samples were collected monthly for alkalinity analyses by digital titration [ASTM 1067 02] and cation analyses by ICP/OES [EPA 200.7]. Water samples were collected from the two sites from the beginning of February 2013 to the middle of January 2015. The timing of this data collection was intended to study any impact to the springs' salinity levels during snow melt, when deicing salt would presumably be washing into and through groundwater supplies. A temperature data logger was installed in Coldwater Spring. The data logger was inserted into a feed pipe along the north side of the springhouse about 3 meters from the outfall pipe.

\section{Data and Interpretation}

Although Coldwater Spring and Wetland A are less than 100 meters apart, their water chemistries and flow rates show differences. Both show significant seasonal fluctuations in many parameters which, in several cases, are mirror images of each other.

\section{Chloride}

Figure 2 displays the chloride concentrations in Coldwater Spring, Wetland A and the Big Culvert during the monitoring period.

\section{Historical Data}

During the $19^{\text {th }}$ Century Coldwater Spring was the water source of the U.S. Army's Fort Snelling in Minneapolis. Army Captain Maguire (1880) reported the chloride level in Coldwater Spring to be 0.26 grains per gallon which is equivalent to $4.5 \mathrm{ppm}$ in modern units. [Early analyses of chloride were done by titration with a clear end-point and are quite reliable.]

\section{Coldwater Spring}

Figure 2 shows that the chloride content of Coldwater Spring's water increased from 320 ppm in March 2013 to 410 ppm in January 2015. Superimposed on the increase of about $45 \mathrm{ppm} /$ year were two pulses between roughly April and July of 2013 and 2014. The first pulse reached $432 \mathrm{ppm}$ on 10 June 2013. The second pulse rose to 455 ppm on 20 May 2014. These chloride levels are about 100 times the levels from 1880 .

Deicing salt is applied to two major multi-lane highways close to the springs throughout the late fall, winter and early spring. If the pulses are attributable to infiltration

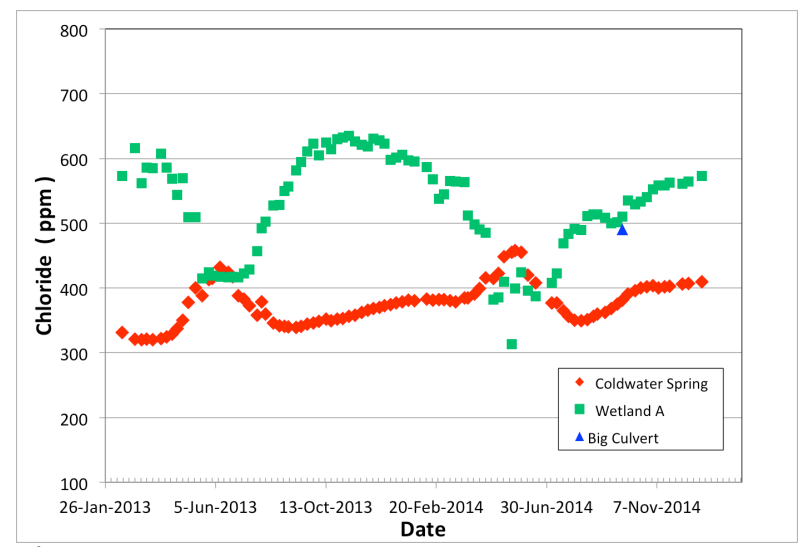

Figure 2. Chloride concentrations in Coldwater Spring, Wetland A and the Big Culvert. 
of road salt runoff, these data suggest it takes about five months for the winter road salt input to reach Coldwater Spring. The magnitude of each year's pulse should depend on the severity of the winter - which fluctuates significantly from year to year depending on the severity of each winter. Ignoring the chloride pulses, chloride levels in Coldwater Spring are very high and generally increased over the period of this study.

\section{Wetland A}

Wetland A chloride levels (Figure 2) were higher than the chloride levels at Coldwater Spring, and displayed an inverse relationship to Coldwater Spring. Wetland A's chloride levels were low when Coldwater Spring's chloride pulses were high - and vice versa. The dips in Wetland A chloride concentrations were greater than the pulses in Coldwater Spring's concentrations, but occurred at essentially the same time. Wetland A's chloride levels ranged from $313 \mathrm{ppm}$ to $632 \mathrm{ppm}$. This mirror image behavior of Coldwater Spring and Wetland A's water quality is repeated in several of the other parameters discussed below. This behavior is cryptic and surprising. We are not aware of any other system that displays this mirror image behavior. Chloride is the most common anion in both Coldwater Spring and Wetland A's water.

\section{Big Culvert}

Only one sample was collected from the Big Culvert. Big Culvert's value is shown in Figure 2 and subsequent graphs. This result is similar to the data seen at Wetland A.

\section{Chloride to Bromide Mass Ratios}

Salts from different sources have different, characteristic chloride to bromide ratios (Davis et al., 1998). In addition to the sewage and rainfall $\mathrm{Cl} /$ $\mathrm{Br}$ ratios, Panno et al. (2006) found $\mathrm{Cl} / \mathrm{Br}$ ratios for softened water ranging between 175 and 1,122 and for agrichemical-affected water with tile drains, from 108 to 1974 . The road salt ratio minimum was 1,164 and ranged up to 4,225. Measurements of the chloride to bromide ratios in Coldwater Spring, Wetland A and Big Culvert help to identify the source of the salt. Figure 3 shows the chloride to bromide mass ratios from the sample sites. It also shows the chloride to bromide mass ratios of three road salt samples taken from different sites on the University of Minnesota campus in winter 2014 .

\section{Coldwater Spring, Wetland $A$ and Big Culvert}

The chloride to bromide ratios in all three sample sites scatter from about 2,000 to 4,500 - well within the range of reported values for road salt. The ratios from the three samples of road salt taken at three different sites around the University of Minnesota campus are in the same range. These data suggest that road salt is the primary contributor to the high chloride levels in Coldwater Spring, Wetland A and the Big Culvert.

\section{Temperature}

\section{Historical Temperature Data for Coldwater Spring}

In 1836 and 1837, a French explorer named Joseph Nicollet measured the temperature of Coldwater Spring in both the summer and the winter months (Nicollet, 1845). He described Coldwater Spring's temperature as:

\begin{abstract}
"Of the numerous springs that issue from the foot of the...bluffs [adjoining Fort Snelling] there is one particularly deserving of notice. It is very abundant and perfectly shaded. It goes by the name of Baker's spring. Having taken its temperature three times a day during twenty days of the month of July, 1836, and then again during the following winter months, I never found it to vary more than $46^{\circ} \mathrm{F}$ in July, and $45.5^{\circ} \mathrm{F}$ in January."
\end{abstract}

Converting the temperatures from Fahrenheit to degrees centigrade, the measured temperature average of Coldwater Spring was about $7.8^{\circ} \mathrm{C}$ in July and $7.5^{\circ} \mathrm{C}$ in the winter. This indicates that in the summer of 1836 and

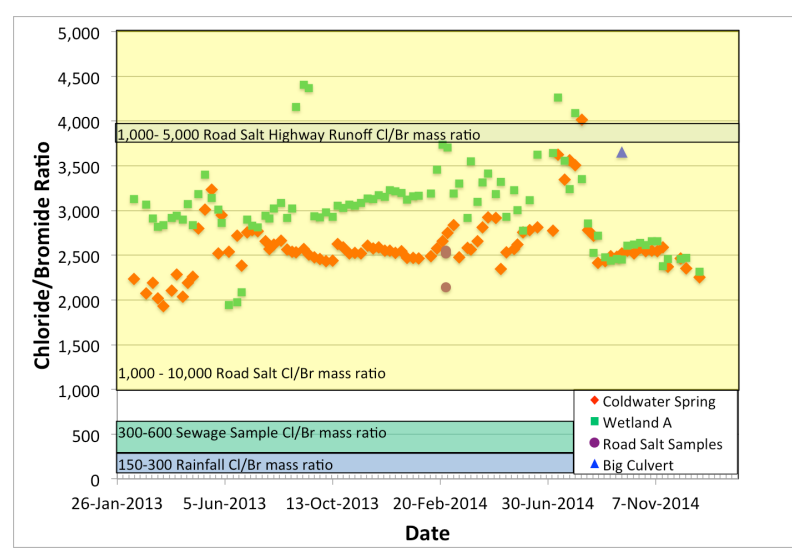

Figure 3. Chloride to bromide mass ratios for Coldwater Spring, Wetland A, Big Culvert, and for two road salt samples taken from different sites on the University of Minnesota campus. 
the winter of 1837, Coldwater Spring's temperature was essentially constant. The temperature of shallow springs is typically the average annual air temperature of that region. The shallow ambient groundwater temperature in this part of Minnesota is about $8^{\circ} \mathrm{C}$.

\section{Temperature Records}

Figure 4 displays the weekly temperatures of Coldwater Spring and Wetland A. The temperature was measured using an ASTM calibrated glass thermometer.

Figure 5 contrasts the weekly temperature records for Coldwater Spring and Wetland A with the average air temperatures on the days that samples were collected. The air temperature data, measured at the Minneapolis/ St. Paul Airport and which is two kilometers from Coldwater Spring, are from the National Weather Service website, as follows: www.crh.noaa.gov/mpx/ Climate/MSPClimate.php.

In Figure 6 the 15 minute interval data logger temperature record from Coldwater Spring is shown in blue. The gaps in the data logger plot are due to equipment problems. The weekly thermometer data from Coldwater Spring (from Figures 4 and 5) is shown in red.

\section{Temperature in Coldwater Spring}

The field thermometer temperature of Coldwater Spring (Figure 4) fluctuated seasonally between $10.7^{\circ} \mathrm{C}$ and $13.1^{\circ} \mathrm{C}$ in a sinusoidal pattern. This is a 3- to 5-degree increase from the 1836 and 1837 temperature levels. Since the temperature fluctuates over a 2.4 degree range, it is clear that Coldwater Spring is no longer a constant temperature spring. The increasing range of spring temperatures may reflect increased urbanization where

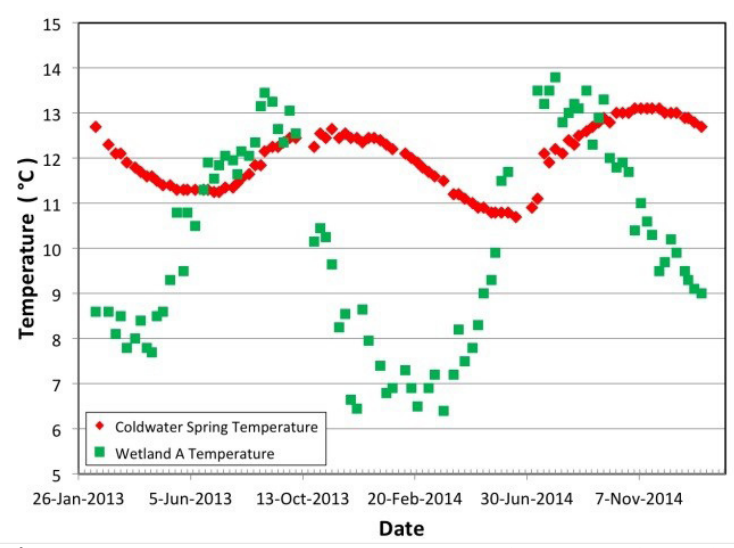

Figure 4. Weekly temperature fluctuations in Coldwater Spring and Wetland A. snow is cleared from roads and parking areas allowing greater frost depths and much higher temperatures under summer sun.

The lowest point in the temperature fluctuations occurs in early June. The highest temperatures occur in early November. In comparison the air temperatures (Figure 5) peak in late July or early August and the minimum temperatures occur in late January to early February. The temperature fluctuations in Coldwater Spring lag air temperature fluctuations by about four to five months.

The data logger record (Figure 6) has relatively smooth, linear temperature profiles with minimal short term variation. The absence of hours to days temperature excursions indicate that the flow path to this sampling point is long enough to even out variations due to storm events but not long enough to average out seasonal effects.

The data logger temperature record is surprisingly different from the thermometer readings record. The shape is closer to a linear zig zag than a sine wave. The maximum and minimum temperatures of the data logger record are 0.3 to $1^{\circ} \mathrm{C}$ higher than those in hand measured temperature record using the thermometer.

Discrepancies in the two temperature plots may be due to the location of the temperature samples taken. The data logger was located in one of the entrance pipes on the north side of the springhouse, and the thermometer samples were taken from the south side of the springhouse in the exit pipe, about ten feet from the data logger. Alternatively, the discrepancies may

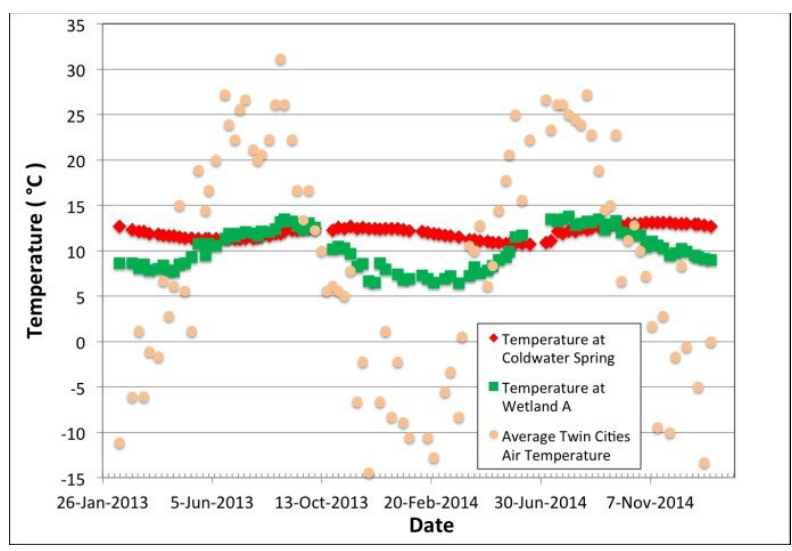

Figure 5. Comparison of air temperatures with the water temperatures in Coldwater Spring and Wetland $A$. 


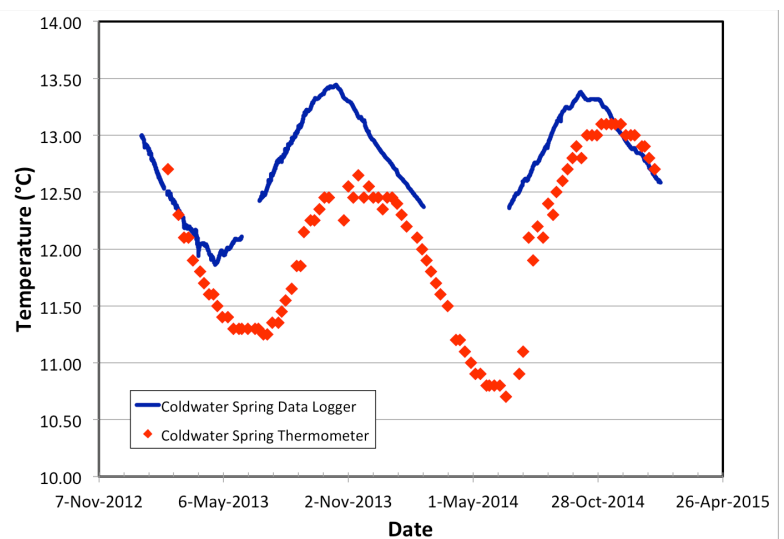

Figure 6. Comparison of the data logger temperatures with the thermometer temperatures in Coldwater Spring.

be evidence for multiple, different water inputs to the Coldwater Springhouse. Such different sources (fed by different flow paths) would be the start of an explanation for the observed chemical and temperature variations.

\section{Temperature in Wetland A}

Wetland A thermometer temperatures ranged between 6.4 and $13.8^{\circ} \mathrm{C}$, with the temperature peaking at the end of August. Wetland $\mathrm{A}$ is also not feed by a constant temperature spring. The Wetland A's water source temperature fluctuation is out of phase with the air temperature by about two months. Wetland A temperatures range from well above to below the average groundwater temperatures of roughly $8^{\circ} \mathrm{C}$. Wetland A's temperatures can be explained as being driven by the air temperatures in a very shallow flow system.

\section{Nitrate-Nitrogen}

The 1974 Safe Drinking Water Act set a national maximum contaminant level (MCL) for nitrate of $10 \mathrm{ppm}$ as an enforceable standard (Water, 2013). Although the nitrate levels in each sample site are below this drinking standard, maximum contaminant levels are purposely set as close as possible to the health goals. Nitrate-nitrogen is an indicator parameter of contamination, and is often accompanied with other pollutants such as pathogenic viruses, bacteria and synthetic organic compounds. Therefore, the elevated levels found in Coldwater Spring and Wetland A are significant and, in this urban setting, suggest contamination from human sources such as lawn fertilizer runoff or leaking sanitary sewage lines.

\section{Nitrate-Nitrogen in Coldwater Spring}

The nitrate-nitrogen levels in Coldwater Spring (Figure 7) varied between $2.6 \mathrm{ppm}$ to $5.2 \mathrm{ppm}$ during this study.
The concentration of nitrate-nitrogen rose by about $2 \mathrm{ppm}$ over two years, and also displayed a sinusoidal pattern. The annual nitrate minima occur almost simultaneously with the highest chlorides. Seasonal application of lawn fertilizers occurs roughly opposite the use of road salt.

\section{Nitrate-Nitrogen Levels in Wetland A}

Wetland A had a wider nitrate-nitrogen level range than Coldwater Spring, varying between about $0.3 \mathrm{ppm}$ and $6.0 \mathrm{ppm}$. Wetland A's nitrate-nitrogen levels vary much more than do Coldwater Spring's but are rising when Coldwater's levels are dropping and vice versa.

\section{Major Ion Chemistry}

Piper Diagrams are a 2D graphical technique for displaying and interpreting the major ion chemistries of water samples (Piper, 1944). The lower left triangle is a ternary diagram of the major dissolved cations. The lower right triangle is a ternary diagram of the major anions. The two triangles are projected into the middle square. Figure 8 is a 3D Piper Diagram where the total concentrations of the dissolved ions are shown by the vertical bars. Figure 8 illustrates that the waters from Coldwater Spring and the waters from Wetland A have roughly similar major ion chemistries, but differ enough to be able to be able to be distinguished. Wetland A's waters contain higher levels anthropogenic ions of sodium, chloride, and nitrate, than Coldwater Spring's waters.

Most springs from carbonate rocks in Minnesota fall closer to the bicarbonate corner of the anion triangle than do the waters Coldwater Spring and Wetland A. Solution of the Platteville Limestone produces calcium, magnesium and bicarbonate ions. Coldwater Spring's anions are about $50 \%$ chloride and Wetland A's anions

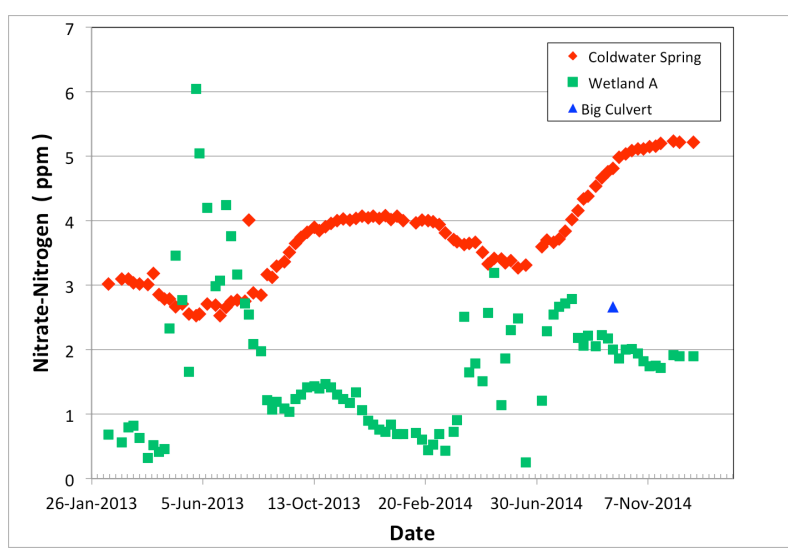

Figure 7. Nitrate-nitrogen levels in Coldwater Spring and Wetland $A$. 


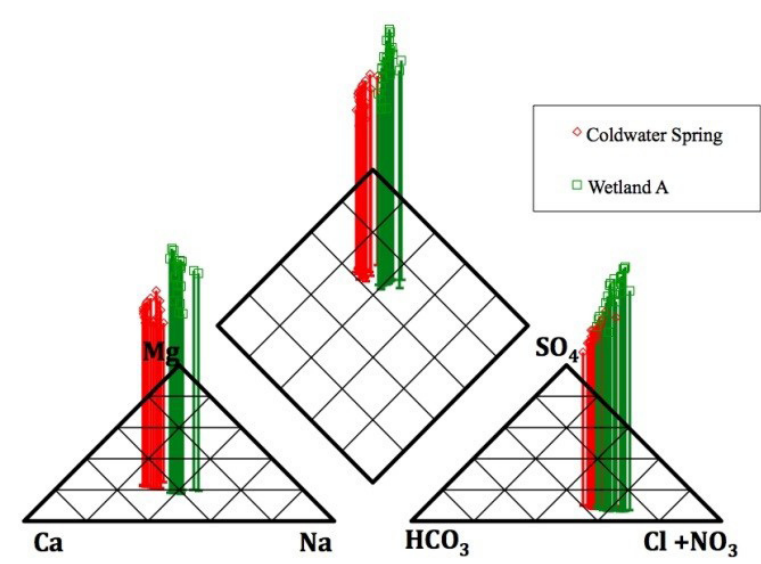

Figure 8. 3D Piper diagram of major cation and anion composition.

are about $60 \%$ chloride in terms of milliequivalents per liter. Both numbers are a measure of the large chloride and nitrate contamination of the spring and wetland water sources.

The large concentrations of chloride in the waters from both sources are not balanced by the sodium concentrations. Cation exchange has occurred along the groundwater pathways in the time between the applications of the road salt, and when the dissolved road salt reaches the springs.

Both Coldwater Spring and Wetland A's waters have relatively constant elevated sulfate ion concentrations of about 80 to $90 \mathrm{ppm}$. These values are probably produced naturally from the oxidation of sulfides present in the Platteville Limestone.

\section{Summary and Conclusions}

1. The temperature and water chemistry of the groundwater flowing from Coldwater Spring and Wetland $A$ appear to have been significantly impacted by human activities.

2. The chloride concentrations in Coldwater Spring's waters have increased 100 -fold between 1880 and the present. The chloride contents in Wetland A's waters are even higher than those in Coldwater Spring. The chloride/ bromide ratios in both springs suggest that road salt is likely the primary source of the chloride. The chloride contents of Coldwater Spring and Wetland A fluctuate in mirror image fashion: one is high when the other is low and vice versa.
3. Coldwater Spring is no longer a constant temperature spring. Coldwater Spring's temperature fluctuates smoothly by $2.4^{\circ} \mathrm{C}$. The temperatures are 3 to $5^{\circ} \mathrm{C}$ warmer than the temperatures of the spring in 1837. The temperature fluctuations are not in phase with seasonal air temperatures. Coldwater Spring's waters are coolest in June and warmest in November. Dense urbanization of the region around Coldwater Spring has driven larger seasonal variation in soil temperature and higher temperatures overall.

4. Wetland A is fed by a shallow and more local ground water recharge area than Coldwater Spring. Wetland $\mathrm{A}$ has larger temperature fluctuations than Coldwater Spring and is only slightly out of phase with the seasonal air temperature.

5. Coldwater Spring's nitrate-nitrogen levels rose from about 3 ppm in February 2013 to over 5 ppm in January 2015. The nitrate-nitrogen values in Coldwater Spring vary inversely with chloride. One potential source of nitrate-nitrogen is leaking sanitary sewage lines, but one would expect that input would be a more constant nitrate source year-round. A second source is larger pulses of nitrate from seasonal lawn fertilizer applications which occur during the spring and summer - in different seasons than the road salt applications.

6. Wetland A's nitrate levels peak in the spring at $6 \mathrm{ppm}$ but are generally lower than Coldwater Spring, around $1 \mathrm{ppm}$ through most of the summer and winter. This may reflect the more locally dominated recharge and lack of fertilizer application on the Coldwater Spring property and adjacent roadways.

\section{Future Work}

In addition to the potential for multiple water inputs to the Coldwater Springhouse, NPS staff and the Howe and Lauzon (2014) report identified three additional artificial drains of the Coldwater Spring area - two old drain pipes to the east and one additional drain pipe to the south. All of these places where ground water returns to the surface need to be monitored and their chemical and physical properties documented.

Dye tracing will be a significant tool to determine the possible recharge areas for the Coldwater Spring site in this complex urban environment. Alexander et al. (2001) 
documented connections to Coldwater Spring from two, nearby points, but did not monitor any of the other potential resurgences.

A dye trace is currently being conducted at Coldwater Spring. Rhodamine and uranine/fluorescein dyes were poured into two separate rain gardens in the Veteran's Hospital, located across Highway 55 from Coldwater Spring on 6 June 2015. Eight dye bugs were placed around the Coldwater Spring site to track the movement of the dyes through the groundwater system at Coldwater Spring. Figure 9 shows the various input and monitoring points. We hope to have dye trace results to report by the $14^{\text {th }}$ Sinkhole Conference.

\section{Acknowledgments}

A special thanks goes to the National Park Service for partial funding of this project and for NPS staff assistance and encouragement. Another special thanks to the University of Minnesota's Undergraduate Research

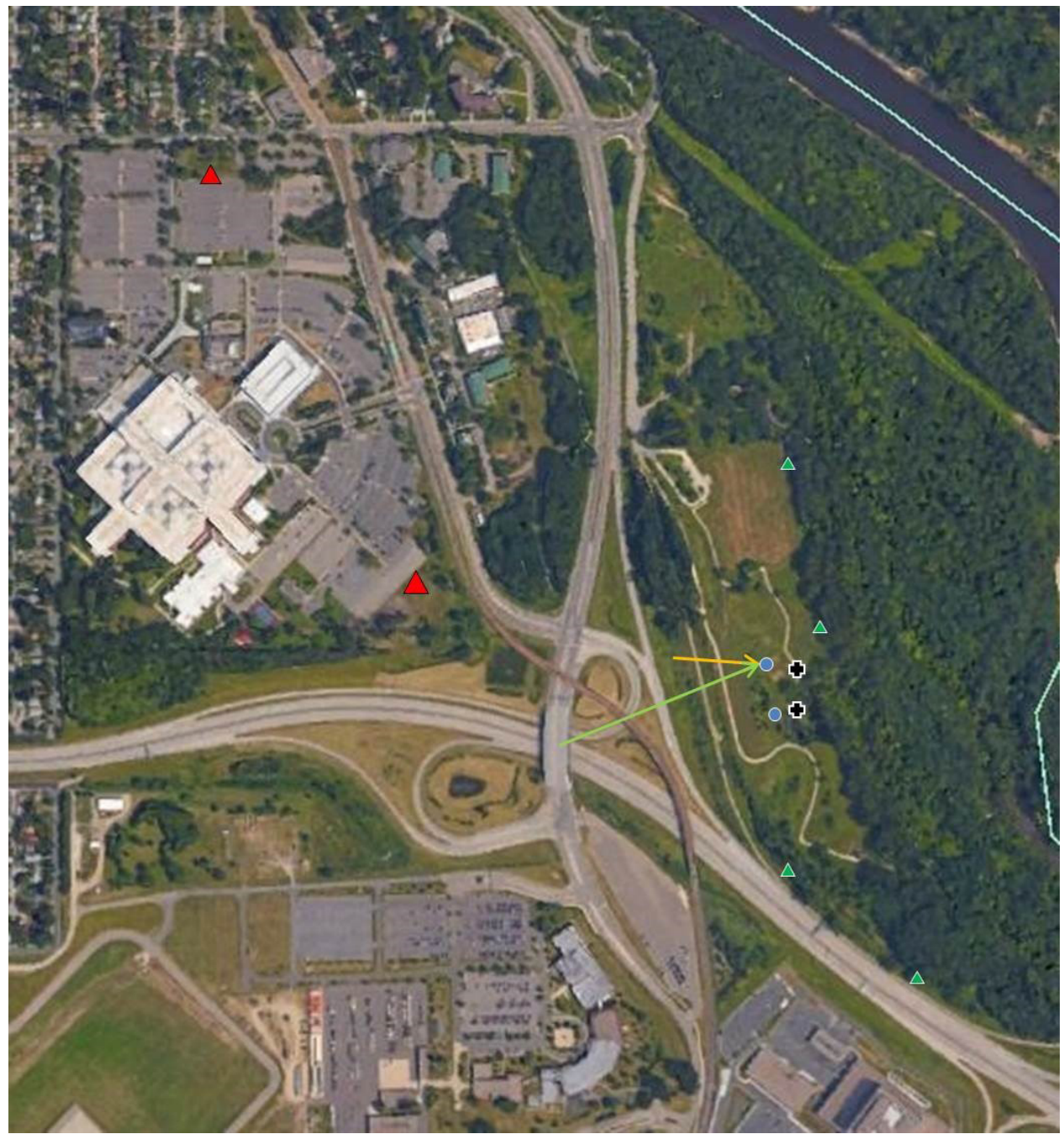

Figure 9. Map showing the relationships between the TH62/TH55 traffic interchange, the Minneapolis VA Medical Center and the Coldwater Spring Mississippi National River \& Recreation Area. The two blue circles show Coldwater Spring (upper) and Wetland A Spring (lower). The orange and green arrows show the results of 2001 dye traces (Alexander et al., 2001). The two red triangles show the 2015 dye input points in the northern parking lot rain garden (upper) and southeastern parking lot rain garden (lower). The green triangles show the outfall pipes of drainage and storm water drains. The two black crosses are sampling locations under the foot bridges across the Coldwater and Wetland A spring runs. Charcoal detectors were placed and are being periodically changed at the eight locations shown by the blue circles, black crosses and green triangles. 
Opportunities Program for partially funding this project and for the opportunity to present the preliminary results at the National Conference on Undergraduate Research in April 2014. SMK would also like to thank her father Hisanao for taking her sampling every week throughout the school year and the cold Minnesota winter, and to her mother Susan for driving her to and from the University of Minnesota campus during the summer. We thank Betty Wheeler for her editing of this paper.

\section{References}

Alexander EC Jr., Alexander SC, Barr K. 2001. Dye Tracing to Camp Coldwater Spring, Minneapolis, MN. Minn. Groundwater Assoc. Newsletter 20 (4): 4-6.

Corsi S, De Cicco L, Lutz M, Hirsch R. 2014. River chloride trends in snow-affected urban watersheds: increasing concentrations outpace urban growth rate and are common among all seasons. Science of The Total Environment 508:488-497. www.sciencedirect.com/science/ article/pii/S0048969714017148.

Davis SN, Whittemore DO, Fabryka-Martin J. 1998. Uses of Chloride/Bromide Ratios in Studies of Potable Water. Ground Water 36 (2): 338-350.

Homstad M. 2010. Hold the salt. In: Minnesota Conservation Volunteer. January-February, 2010. St. Paul (MN): Minnesota Department of Natural Resources: 62-63. www.dnr.state.mn.us/ mcvmagazine/archive.html.

Howe C, Lauzon B. 2014. Safeguarding Coldwater Spring. Minnesota Department of Transportation Right-of-Way.

Kasahara SM. 2014. Chloride monitoring at Coldwater Spring. In: Snow DM, Guerrant B, co-chairs. 28th National Conference on Undergraduate Research, April 3-5, 2014. Lexington (KY): The University of Kentucky. www.ncurproceedings.org/ojs/index. php/NCUR2014.

Keseley S. 2007. From icy roads to salty waters: road salt effects on our environment. [Internet]. [Place of publication unknown]: The Illinois Association of Public Procurement Officials, Inc. Available from: http://juarezprojectcitizen. wikispaces.com/file/view/IAPPO07 RoadSalt. pdf.

Local climate records. [Internet]. 1995. [Place of publication unknown]: National Weather Service Weather Forecast Office. National Oceanic and Atmospheric Administration. Available from: http://www.crh.noaa.gov/mpx/Climate/ MSPClimate.php.
Maguire E. 1880. Press copies of office letters sent by Captain Edward Maguire, Chief Engineer, June 26, 1880. In: The Water. Department of Dakota., p. 2

MAR 4725. 2013. Minnesota Administrative Rules, Chapter 4725. Wells and borings. [Internet]. St. Paul (MN): State of Minnesota. Office of the Revisor of Statutes. Available from: https://www. revisor.mn.gov/rules/?id=4725.

Mohseni O, Stefan HG. 2006. Study of environmental effects of de-icing salt on water quality in Minnesota. [Internet]. Minneapolis (MN): University of Minnesota Center for Transportation Studies. Available from: http://www.cts.umn.edu/ Research/ProjectDetail.html?id=2006071.

Nicollet JN. 1845. Report intended to illustrate a map of the hydrographical basin of the Upper Mississippi River. [Internet]. 1845. Document of the US House of Representatives. 28th Congress, 2nd Session, no. 52. Washington (DC): Blair and Rives. http://www.worldcat.org/ title/report-intended-to-illustrate-a-map-of-thehydrographical-basin-of-the-upper-mississippiriver/oclc/166586906?referer=di\&ht=edition.

NPS. 2012. Coldwater Spring Restoration Project. Mississippi National River and Recreation Area. [Internet]. [Place of publication unknown]: National Park Service. US Department of the Interior. Available from: http://www.nps.gov/miss/ parkmgmt/bomcurr.htm.

Panno S, Hackley K, Hwang H, Greenberg S, Krapac I, Landsberger S, O'Kelly D. 2006. Characterization and Identification of $\mathrm{Na}-\mathrm{Cl}$ Sources in Groundwater. Groundwater 44(2):176-187.

PCCC. 2012. Preserve Camp Coldwater coalition. [Internet]. [Place of publication unknown]: Preserve Camp Coldwater Coalition. Available from: http://www.preservecampcoldwater.org/ index.html.

Piper, AM. 1944. A graphical procedure in the geochemical interpretation of water analyses. American Geophysical Union Transactions 25: 914-923.

Rastogi N. [Internet] 2010. Does road salt harm the environment? [Place of publication unknown]: Slate.com. Available from: http://www.slate. com/articles/health_and science/the green lantern/2010/02/salting the earth.html.

Sander A, Novotny E, Mohseni O, Stefan H. 2007. Inventory of road salt use in the Minneapolis/St. Paul Metropolitan Area. Minneapolis (MN): St. Anthony Falls Laboratory. Available from: http:// purl.umn.edu/115332. 
Shen Z, Konishi H, Brown PE, Xu H. 2013. STEM investigation of exsolution lamellae and "c" reflections in Ca-rich dolomite from the Platteville Formation, western Wisconsin. American Mineralogist 98 (4): 760-766. Available from: http://www.minsocam.org/MSA/AmMin/ TOC/2013/Apr13.html.

Stefan HG, Novotny E, Sander A, Mohseni O. 2008. Study of environmental effects of de-icing salt on water quality in the Twin Cities Metropolitan Area, Minnesota. Report no. MN/RC 200842. St. Paul, MN: Minnesota Department of Transportation. Available from: http://www.lrrb. org/media/reports/200842.pdf.

UMCTS. 2006. Minneapolis, MN: University of Minnesota Center for Transportation Studies. Available from: http://www.cts.umn.edu/Research/ ProjectDetail.html?id=2006071.

Water. 2013. Basic information about regulated drinking water contaminants. [Internet]. [Place of publication not available]: US Environmental Protection Agency. Available from: http://water. epa.gov/drink/contaminants/basicinformation/. 